\title{
A METHOD FOR FINDING THE STEP SIZE OF INTEGRATION OF A SYSTEM OF ORDINARY DIFFERENTIAL EQUATIONS
}

In this paper we give a method for finding the step size of integration of an initial value problem. This method can be used with a slight modification in other numerical problems (see [1]). Some numerical results are presented which show the advantages of the method.

1. Method of choice of the step size. The initial value problem which we wish to solve numerically is

$$
y^{\prime}=f\left(x, y_{i}\right), \quad y(a)=y_{0}, \quad x \in[a, b], \quad y, f \in R^{n}
$$

Let (1.1) have a unique solution. For the numerical solution of this problem we apply a one-step method of rank $p(p \geqslant 1)$ and of the form

$$
\begin{cases}\eta_{k}^{0}=y_{0 k} & \\ \eta_{k}^{i+1}=\eta_{k}^{i}+h_{i} \Phi\left(x, \eta_{1}^{i}, \eta_{2}^{i}, \ldots, \eta_{n}^{i}, h_{i}\right) & (i=0,1, \ldots) .\end{cases}
$$

In the case of one equation $(n=1)$, one of the possible methods for finding the step size $h_{i}$ was given by Krylov ([2], p. 103-107) and Stoer ([3], p. 114-118). In this paper we apply this method to the general case of a system of ordinary differential equations. Let $\eta_{k}\left(x_{0}+h, h\right)$ denote the approximation of the solution of problem (1.1) at the point $x_{0}+h$ obtained from (1.2) with step size $h$ and let $\eta_{k}\left(x_{0}+h, h / 2\right)$ denote the approximation of this solution by twofold application of (1.2) with step size $h / 2$.

For one-step methods of rank $p$ we have (see [2])

$$
y_{k}\left(x_{0}+h\right)=\eta_{k}\left(x_{0}+h, h\right)+C_{k}^{0}\left(x_{0}\right) h^{p+1}+C_{k}^{1}\left(x_{0 k}\right) h^{p+2} \quad(k=1,2, \ldots, n),
$$


where $x_{0 k}$ are the points from $\left[x_{0}, x_{0}+h\right], y_{k}(x)$ is the exact solution of (1.1), and $C_{k}^{i}(x)$ are any continuous functions independent of $h$. Since we are interested only in the rank of the error, we can write

$$
y_{k}\left(x_{0}+h\right)-\eta_{k}\left(x_{0}+h, h\right) \doteq C_{k}\left(x_{0}\right) h^{p+1}
$$

and

$$
y_{k}\left(x_{0}+h\right)-\eta_{k}\left(x_{0}+h, h / 2\right) \doteq 2 C_{k}\left(x_{0}\right)(h / 2)^{p+1}
$$

for $k=1,2, \ldots, n$, where $C_{k}\left(x_{0}\right)=C_{k}^{0}\left(x_{0}\right)$.

The derivation of formula (1.4) is as follows:

From (1.3) with step size $h / 2$ at the point $x_{0}$ we have

$$
y_{k}\left(x_{0}+h / 2\right)-\eta_{k}\left(x_{0}+h / 2, h / 2\right) \doteq C_{k}\left(x_{0}\right)(h / 2)^{p+1}
$$

Applying this formula twice at the points $x_{0}, x_{0}+h / 2$ with $h / 2$ we have

$$
\begin{aligned}
y_{k}\left(x_{0}+h\right) \doteq y_{k}\left(x_{0}\right)+\frac{h}{2} \Phi\left(x_{0}, y_{1}\left(x_{0}\right), y_{2}\left(x_{0}\right), \ldots, y_{n}\left(x_{0}\right), \frac{h}{2}\right)+ \\
+C_{k}\left(x_{0}\right)\left(\frac{h}{2}\right)^{p+1}+\frac{h}{2} \Phi\left(x_{0}+\frac{h}{2}, y_{1}\left(x_{0}+\frac{h}{2}\right), y_{2}\left(x_{0}+\frac{h}{2}\right), \ldots, y_{n}\left(x_{0}+\frac{h}{2}\right), \frac{h}{2}\right)+ \\
+C_{k}\left(x_{0}+\frac{h}{2}\right)\left(\frac{h}{2}\right)^{p+1}
\end{aligned}
$$

Since we omit elements with the exponent $h$ greater than $p+1$, we can write

$$
C_{k}\left(x_{0}+h / 2\right)(h / 2)^{p+1} \doteq C_{k}\left(x_{0}\right)(h / 2)^{p+1} .
$$

Using this formula and replacing $y_{1}\left(x_{0}+h / 2\right), \ldots, y_{n}\left(x_{0}+h / 2\right)$ by suitable values from (1.5) and omitting elements with the exponent $h$ greater than $p+1$ in the Taylor series $\Phi$, we have

$$
y_{k}\left(x_{0}+h\right) \doteq \eta_{k}\left(x_{0}+h, h / 2\right)+2 C_{k}\left(x_{0}\right)(h / 2)^{p+1} \quad(k=1,2, \ldots, n) .
$$

From (1.3) and (1.4) we obtain

$$
\begin{array}{r}
\Delta_{k}=\eta_{k}\left(x_{0}+h, \frac{h}{2}\right)-\eta_{k}\left(x_{0}+h, h\right) \doteq C_{k}\left(x_{0}\right) h^{p+1} \frac{2^{p}-1}{2^{p}} \\
(k=1,2, \ldots, n) .
\end{array}
$$

Let $H$ denote the integration step which gives an approximation of the solution with given error and let $\varepsilon$ denote the error vector. We want to obtain

$$
\varepsilon_{k} \geqslant\left|y_{k}\left(x_{0}+H\right)-\eta_{k}\left(x_{0}+H, H\right)\right| \doteq\left|C_{k}\left(x_{0}\right) H^{p+1}\right| \quad(k=1,2, \ldots, n) .
$$


Let $H=h / \omega$. By (1.7) we can write

$$
\varepsilon_{k} \geqslant\left|C_{k}\left(x_{0}\right) H^{p+1}\right|=\left|C_{k}\left(x_{0}\right)(h / \omega)^{p+1}\right|,
$$

and using (1.6) we have

$$
\varepsilon_{k} \geqslant \frac{\left|\Delta_{k}\right| 2^{p}}{\omega^{p+1}\left(2^{p}-1\right)} \quad(k=1,2, \ldots, n) .
$$

Finally, for finding $\omega$ which designates $H$ we have

$$
\omega=a \sqrt[p+1]{\frac{2^{p}}{2^{p}-1} \max _{1 \leqslant k \leqslant n} \frac{\left|\Delta_{k}\right|}{\left|\varepsilon_{k}\right|},}
$$

where the constant $a>1$ is introduced for the algorithm to work.

It is clear from (1.3) that the error of the obtained solution is $O\left(H^{p+1}\right)$. Applying Richardson's extrapolation we obtain

$$
\begin{array}{r}
\eta_{k}^{*}\left(x_{0}+H\right)=\eta_{k}\left(x_{0}+H, \frac{H}{2}\right)+\frac{\eta_{k}\left(x_{0}+H, H / 2\right)-\eta_{k}\left(x_{0}+H, H\right)}{2^{p}-1} \\
(k=1,2, \ldots, n),
\end{array}
$$

where $\eta_{k}^{*}\left(x_{0}+H\right)$ is a solution with error $O\left(H^{p+2}\right)$.

We may accept this value as the exact value to the next step of method (1.2).

The numerical realization of this method is shown in Fig. 1.

2. The procedure diffsystrunkut4. The procedure diffsystrunkut4 calculates the approximate values $y_{1}(x), y_{2}(x), \ldots, y_{n}(x)$ of the solutions of the system of differential equations

$$
\begin{gathered}
y_{k}^{\prime}=f_{k}\left(x, y_{1}, y_{2}, \ldots, y_{n}\right), \\
y_{k}\left(x_{0}\right)=y_{0 k}
\end{gathered}
$$

for $k=1,2, \ldots, n(n \geqslant 1)$ using the standard Runge-Kutta method of fourth order.

Data:

$x 0$ - parameter in (2.2);

$x 1$ - value of $x$ for which we want to obtain a solution of (2.1);

eps, eta - positive parameters $\varepsilon, \eta$ characterizing the precision of the solutions;

hmin - the minimum admissible absolute value of the step size $h$;

$n$ - number of equations;

$y 0[1: n]-$ values of $y_{0 k}$ in $(2.2)$.

Results :

$x 0$ - given value of $x 1$;

$y 0[1: n]$ - approximate values of $y_{k}\left(x_{1}\right)(k=1,2, \ldots, n)$. 


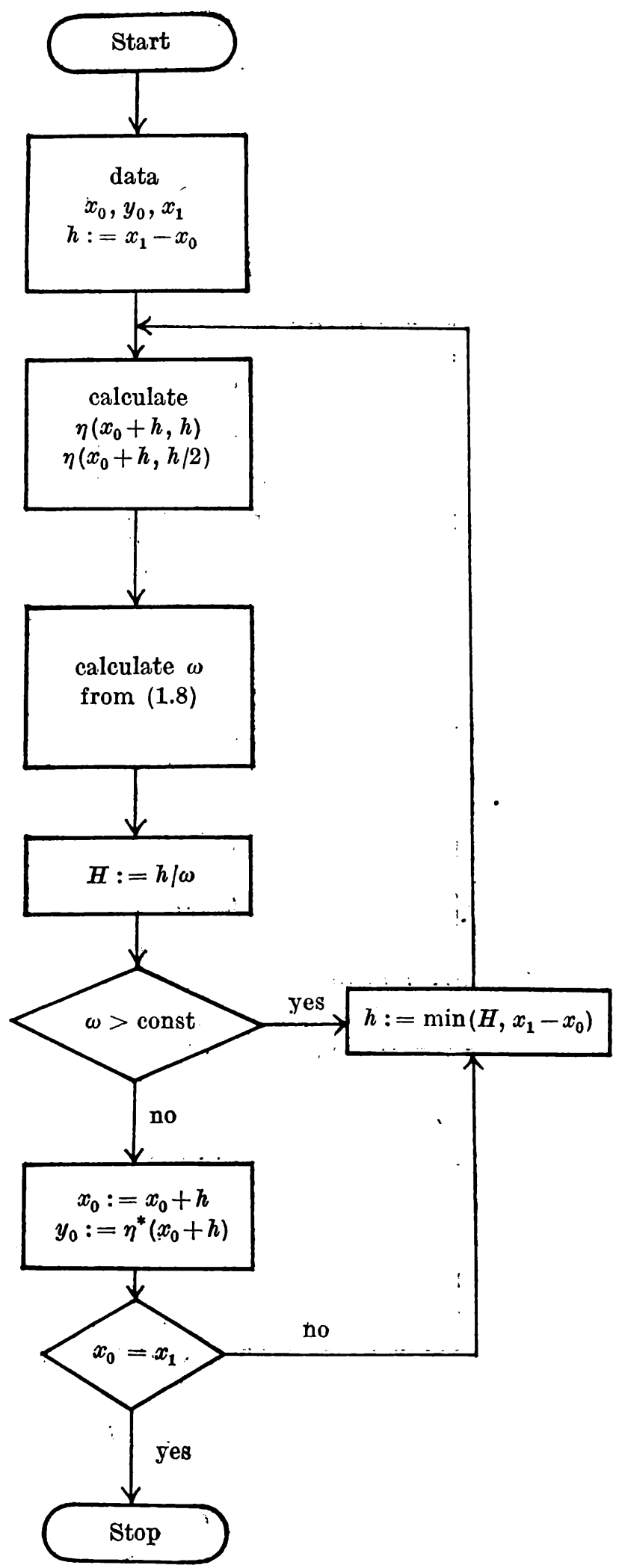

Fig. 1. Flow diagram of they method 
procedure diffêstrunkut $4(20, x 7$, eps, eta, hmin, $n$, yo, notace, 1$)$;

Vrlue $\times 1,0 p 8,0 t a, \ln I n, \mathrm{n}$;

real 20,21,0ps, ota,hmin;

integer $n$;

eirar J0;

lebel notace;

procedure f;

begin

real $b, h h, w i, \pi 1, \pi 2, \pi 3, \pi 4 ;$

Integer 1;

Boolean last;

array $k 1, \mathrm{Jh}, \mathrm{y} 1, \mathrm{~J} 2, \mathrm{y} 3[1: \mathrm{n}]$;

procedure eteprunkut $(h, x, y, d f)$;

velue $h, x$;

real $\mathrm{h}, \mathrm{x}$;

arrar $7, d f ;$

begin

-1 $18 \pi 48=.5 \times 6$;

T28 $=0 ;$

for 1::1 step 1 until $n$ do

besin

$\mathrm{Jh}[1]:=\mathrm{J}[1]$

af $[1]:=00$

ond 1;

for $w 3:=74, h, h, w 4$ do

begin

$f(\pi 2, n, J h, k 1)$;

for $1:=1$ atep 1 until $n$ do

begin

พ2: =k1[1]; 


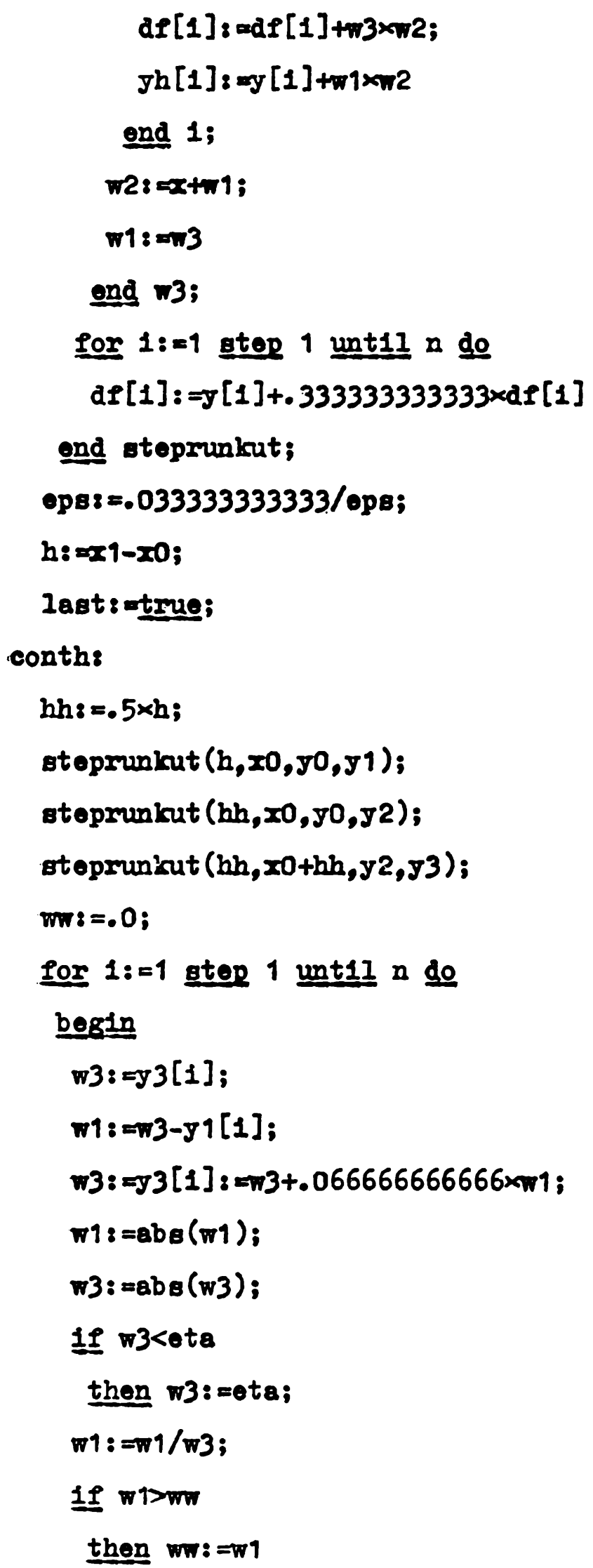


end 1;

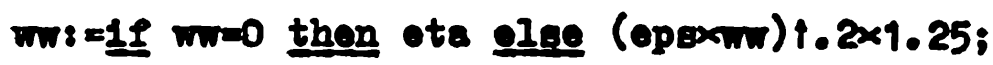

$\mathrm{hh} 8 \mathrm{~m} / \mathrm{wW}$;

1f $m>1.25$

then

begin

If $a b s(\mathrm{hh})<\mathrm{mmin}$

thon 80 to notaco;

last 8 - falge

end $m>1.25$

else

begin

$208=00+h ;$

Ler $18=1$ ater 1 until a do

รO[1]: $\rightarrow 3[1] ;$

if last

then EO to ond;

-18 $-2 x 1-2008$

If $(\nabla 1-h h) \times h<0$

then

besin

hh8 =ा7?;

18ate otrus

end $(w 1-h h) \times h<0$

end $m<1.25$;

h8 =hh;

Eo to conth;

ends

end diffsystrunkut4

8 - Zastos. Mat. 17.4 
Other parameters:

notace - label (outside of the body of the procedure diffsystrunkut4) to which an exit is made if the computed step size $h$ is smaller than hmin.

Remark. After a jump to notace the variable $x 0$ has the value of $x$ $(x \in[x 0, x 1))$ for which a corrcet solution was obtained and the array yo contains this solution.

$f$ - identifier of the prccedure with the head

procedure $f(x, n, y, d)$;

value $x, n, y$;

real $x$;

integer $n$;

array $y, d$;

which for given $n, x$, and $y[1: n]$ computes the values of $d[1: n]$ of the right-hand side of $(2.1)$.

3. Examples of the use of the procedure. We give three examples of the use of the procedure diffsystrunkut4.

As the first example we take a problem which was given by Stoer ([3], p. 117-118):

$$
y^{\prime}=-200 x y^{2}, \quad y(-3) \stackrel{\cdots}{=} 1 / 901
$$

with the exact solution $y(x)=1 /\left(1+100 x^{2}\right)$. We obtained the following results:

\begin{tabular}{c|c|c}
\hline$(\eta-y(0)) / y(0)$ & $\begin{array}{c}\text { Number of evalu- } \\
\text { ations of the } \\
\text { right-hand side }\end{array}$ & eps = eta \\
\hline$-7.246325 \cdot 10^{-3}$ & 276 & $10^{-5}$ \\
$-5.561725 \cdot 10^{-4}$ & 456 & $10^{-6}$ \\
$-5.636424 \cdot 10^{-5}$ & 732 & $10^{-7}$ \\
$-4.719455 \cdot 10^{-6}$ & 1152 & $10^{-8}$ \\
$-5.210094 \cdot 10^{-7}$ & 1848 & $10^{-9}$
\end{tabular}

The remaining two examples are the following:

Example A.

$$
\left\{\begin{array} { l } 
{ y _ { 1 } ^ { \prime } = 1 / y _ { 2 } , y _ { 1 } ( 0 ) = 1 , } \\
{ y _ { 2 } ^ { \prime } = - 1 / y _ { 1 } , y _ { 2 } ( 0 ) = 1 , }
\end{array} \text { with the solution } \left\{\begin{array}{l}
y_{1}(x)=e^{x} \\
y_{2}(x)=e^{-x}
\end{array}\right.\right.
$$

Example B.

$$
\left\{\begin{array} { l } 
{ y _ { 1 } ^ { \prime } = y _ { 2 } , y _ { 1 } ( 0 ) = 0 , } \\
{ y _ { 2 } ^ { \prime } = - y _ { 1 } , y _ { 2 } ( 0 ) = 1 , }
\end{array} \text { with the solution } \left\{\begin{array}{l}
y_{1}(x)=\sin x \\
y_{2}(x)=\cos x
\end{array}\right.\right.
$$


For these examples we obtained results which are given in Tables A and B, respectively. For comparison Table A presents also results obtained with the library procedure RungeKutta4 [4].

TABLE A

\begin{tabular}{|c|c|c|c|c|}
\hline \multirow[b]{2}{*}{$x$} & \multicolumn{2}{|c|}{ diffsystrunkut4 } & \multicolumn{2}{|c|}{ RungeKutta4 } \\
\hline & $\begin{array}{c}\text { Errors for } \\
e p s=e t a=10^{-9}\end{array}$ & $\begin{array}{l}\text { Number of } \\
\text { evaluations } \\
\text { of the right- } \\
\text { hand side }\end{array}$ & $\begin{array}{c}\text { Errors for } \\
e p s=e t a=10^{-9}\end{array}$ & $\begin{array}{l}\text { Number of } \\
\text { evaluations } \\
\text { of the right- } \\
\text { hand side }\end{array}$ \\
\hline 0.5 & $\begin{array}{l}3.53 \cdot 10^{-11} \\
0.00 \cdot 10^{0}\end{array}$ & 132 & $\begin{array}{r}-7.06 \cdot 10^{-11} \\
2.39 \cdot 10^{-11}\end{array}$ & 224 \\
\hline 1.0 & $\begin{array}{r}-4.28 \cdot 10^{-11} \\
1.58 \cdot 10^{-10}\end{array}$ & 132 & $\begin{array}{r}-1.07 \cdot 10^{-10} \\
7.91 \cdot 10^{-11}\end{array}$ & 224 \\
\hline 1.5 & $\begin{array}{r}-1.29 \cdot 10^{-10} \\
2.44 \cdot 10^{-10}\end{array}$ & 132 & $\begin{array}{r}-7.79 \cdot 10^{-11} \\
8.15 \cdot 10^{-11}\end{array}$ & 224 \\
\hline 2.0 & $\begin{array}{r}-2.52 \cdot 10^{-10} \\
3.49 \cdot 10^{-10}\end{array}$ & 132 & $\begin{array}{r}-1.57 \cdot 10^{-10} \\
1.07 \cdot 10^{-10}\end{array}$ & 224 \\
\hline 4.0 & $\begin{array}{r}-5.79 \cdot 10^{-10} \\
9.18 \cdot 10^{-10}\end{array}$ & 492 & $\begin{array}{r}-1.87 \cdot 10^{-10} \\
2.48 \cdot 10^{-11}\end{array}$ & 816 \\
\hline 10.0 & $\begin{array}{r}-4.61 \cdot 10^{-9} \\
5.86 \cdot 10^{-9}\end{array}$ & 1416 & $\begin{array}{r}1.51 \cdot 10^{-9} \\
-1.58 \cdot 10^{-9}\end{array}$ & 3136 \\
\hline
\end{tabular}

TABLE'B

\begin{tabular}{|c|c|c|c|c|}
\hline$x$ & $\begin{array}{c}\text { Errors for } \\
e p s=e t a=10^{-3}\end{array}$ & $\begin{array}{c}\text { Number of } \\
\text { evaluations of } \\
\text { the right-hand } \\
\text { side }\end{array}$ & $\begin{array}{c}\text { Errors for } \\
e p s=e t a=10^{-6}\end{array}$ & $\begin{array}{l}\text { Number of } \\
\text { evaluations of } \\
\text { the right-hand } \\
\text { side }\end{array}$ \\
\hline 0.5 & $\begin{array}{l}1.33 \cdot 10^{-6} \\
4.04 \cdot 10^{-6}\end{array}$ & 12 & $\begin{array}{l}3.27 \cdot 10^{-8} \\
4.75 \cdot 10^{-8}\end{array}$ & 48 \\
\hline 1.0 & $\begin{array}{l}5.37 \cdot 10^{-6} \\
1.03 \cdot 10^{-5}\end{array}$ & 12 & $\begin{array}{l}1.43 \cdot 10^{-7} \\
1.99 \cdot 10^{-7}\end{array}$ & 36 \\
\hline 1.5 & $\begin{array}{l}1.00 \cdot 10^{-5} \\
5.85 \cdot 10^{-5}\end{array}$ & 12 & $\begin{array}{l}1.92 \cdot 10^{-7} \\
6.21 \cdot 10^{-7}\end{array}$ & 48 \\
\hline 2.0 & $\begin{array}{l}1.57 \cdot 10^{-5} \\
3.72 \cdot 10^{-6}\end{array}$ & 12 & $\begin{array}{l}2.45 \cdot 10^{-7} \\
1.53 \cdot 10^{-7}\end{array}$ & 48 \\
\hline 2.5 & $\begin{array}{l}2.47 \cdot 10^{-5} \\
1.28 \cdot 10^{-5}\end{array}$ & 12 & $\begin{array}{l}4.14 \cdot 10^{-7} \\
3.02 \cdot 10^{-7}\end{array}$ & 36 \\
\hline 3.0 & $\begin{array}{l}6.84 \cdot 10^{-5} \\
1.95 \cdot 10^{-5}\end{array}$ & 12 & $\begin{array}{l}8.09 \cdot 10^{-7} \\
3.79 \cdot 10^{-7}\end{array}$ & 48 \\
\hline 3.5 & $\begin{array}{l}2.66 \cdot 10^{-6} \\
2.69 \cdot 10^{-5}\end{array}$ & 12 & $\begin{array}{l}2.32 \cdot 10^{-7} \\
4.17 \cdot 10^{-7}\end{array}$ & 84 \\
\hline
\end{tabular}

In all presented examples hmin was equal to $10^{-6}$.

The procedure diffsystrunkut4 has been verified on the Odra 1204 computer (with 38-bit mantissa) in the Institute of Computer Science of the University of Wrocław. 


\title{
References
}

[1] J. S. Chomicz, Rozwiazanie liniowego zagadnienia brzegowego metoda kollokacji, Report no. N-65, Institute of Computer Science, University of Wrocław, 1979.

[2] V. I. Krylov, V. V. Bobkov and P. I. Monastyrny ı (В. И. Крылов, В. В. Бобков п П. И. Монастырный), Вынислительные методы өысией математики, том 2, Минск 1975.

[3] J. Stoer and R. Bulirsch, Einführung in die numerische Mathematik, II, Berlin 1973.

[4] Systemy programowania maszyny cyfrowej Odra 1204, Zeszyt 1204-VIII-11, MeraElwro, Wrocław 1974.

INSTITUTE OF COMPUTER SCIENCE

UNIVERSITY OF WROCEAW

51-151 WROCEAW

Received on 7. 3. 1978;

revised version on 4.4 .1979

J. S. CHOMICZ, A. OLEJNICZAK I M. SZYGZKOWICZ (Wroelaw)

\author{
METODA ZNAJDO WANIA KROKU CALKO WANIA \\ UKLADU RÓ WNAF RÓZNICZKO WYCH Z WYCZAJNYCH
}

\section{STRESZOZENIE}

W pracy podana jest metoda znajdowania kroku calkowania zagadnienia początkowego (1.1). Jest to uogólnienie na przypadek układu równań różniczkowych pierwszego rzędu metod podanych przez Kryłowa ([2], str. 103-107) oraz Stoera ([3], str. 114-118). Po prostych modyfikacjach metode można stosowá́ także do niektórych innych zagadnień [1].

W pracy zamieszczono procedure realizującą przedstawioną metodę oraz wyniki testów wykonanych na m.c. Odra $1204 \mathrm{w}$ Instytucie Informatyki Uniwersytetu Wrocławskiego. 